\title{
PENGETAHUAN REMAJA PUTRI TENTANG PEMERIKSAAN PAYUDARA SENDIRI (SADARI) DENGAN PERILAKU SADARI
}

\author{
Utama Ladunni Lubis \\ Akademi Kebidanan Alifa Pringsewu \\ Email: unnilubis.olfianwari@gmail.com
}

\begin{abstract}
ABSTRAK
Penyakit kanker merupakan salah satu penyebab utama kematian dan jenis kanker yang lebih banyak terjadi pada wanita adalah kanker payudara. Perlu dilakukan upaya untuk pencegahan kanker payudara melalui deteksi dini yang dikenal dengan metode SADARI (pemeriksaan payudara sendiri). Penelitian ini merupakan penelitian survey analitik dengan desain cross sectional. Populasi dalam penelitian ini adalah seluruh siswi kelas XI MA Al-Fatah Natar, sampel diambil sebanyak 70 responden dengan menggunakan teknik simple random sampling. Teknik analisis data yang digunakan adalah univariat dan bivariat dengan uji chi square. Analisis univariat menunjukkan terdapat 36 responden $(51,4 \%)$ pengetahuan cukup dan 56 responden (80\%) siswi kelas XI belum pernah melakukan SADARI. Uji statistik chi square menunjukkan ada hubungan yang signifikan antara pengetahuan tentang pemeriksaan payudara sendiri (SADARI) dengan perilaku SADARI $p$ value 0,016. Tenaga kesehatan diharapkan dapat memberikan penyuluhan tentang kesehatan reproduksi khususnya deteksi dini kanker payudara secara kontinyu.
\end{abstract}

Kata Kunci: Pengetahuan, Perilaku, SADARI

\section{THE ADOLESCENT KNOWLEDGE OF BREAST SELF-EXAMINATION WITH BREAST SELF-EXAMINATION BEHAVIOR}

\begin{abstract}
Cancer is one of the leading causes of death and the most common type of cancer in women is breast cancer. Efforts should be made to prevent breast cancer through early detection known as the SADARI method. This research is an analytic survey research with cross sectional design. The population in this study were all students of class XI MA Al-Fatah Natar, the sample was taken as much as 70 respondents by using simple random sampling technique. Data analysis technique used is univariate and bivariate with chi square test. Univariate analysis showed 36 respondents (51, 4\%) have sufficient knowledge and 56 respondents (80\%) of grade XI students had never done SADARI. Chi square statistic test showed that there was a significant correlation between knowledge of Pemeriksaan Payudara Sendiri (SADARI) with behavioral SADARI $p$ value 0,016. Health workers are expected to provide counseling about reproductive health, especially early detection of breast cancer continuously.
\end{abstract}

Keywords: Knowledge, Behavior, SADARI

How to Cite: Lubis, U. L. (2017). Pengetahuan Remaja Putri Tentang Pemeriksaan Payudara Sendiri (SADARI) dengan Perilaku Sadari. Aisyah: Jurnal Ilmu Kesehatan. 2 (1), 81 - 86.

\section{PENDAHULUAN}

Penyakit kanker merupakan salah satu penyebab kematian utama di seluruh dunia.
Salah satu penyakit kanker yang lebih banyak terjadi pada wanita adalah kanker payudara yaitu tumor ganas yang tumbuh di 


\section{Aisyah: Jurnal Ilmu Kesehatan 2 (1) 2017, - 82}

Utama Ladunni Lubis

dalam jaringan payudara yang meliputi kelenjar susu, saluran susu, jaringan lemak maupun jaringan ikat pada payudara (Rukiyah, 2012).

\section{Menurut World Health Organization} (WHO,2012), di Indonesia angka kematian yang disebabkan oleh kanker payudara menempati urutan ke-10 setelah kanker paru, sedangkan berdasarkan Riset Kesehatan Dasar (Riskesda, 2013) prevalensi tumor/kanker di Indonesia adalah 1,4 per 1000 penduduk atau sekitar 330.000 orang.

Data Dinas Kesehatan Provinsi Lampung (2012) mencatat bahwa kasus kanker payudara tahun 2012-2013 yang ditemukan sebanyak 906 kasus, dimana Lampung Barat sebanyak 103 (11,36\%), Pringsewu 102 (11,25\%), Way Kanan 98 (10,81\%), Metro 94 (10,37\%), Bandar Lampung 89 (9,71\%), Lampung Selatan 89 (9,71\%), Lampung Utara 81 (8,94\%), Mesuji 79 $(8,71 \%)$, Pesawaran 53 (5,85\%), Tulang Bawang $51(5,62 \%)$, Tulang Bawang Barat $50(5,52 \%)$ dan Kabupaten Pesisir Barat 17 $(1,88 \%)$.

Kasus kanker payudara dari data RSUD dr.H.Abdul Moeloek Provinsi Lampung dalam 5 tahun terakhir mengalami peningkatan, pada tahun 2011 sebanyak 258 pasien, pada tahun 2012 sebanyak 283 dan pada tahun 2013 meningkat tajam menjadi 792 pasien, pada tahun 2014 sebanyak 1.797 pasien dan tahun 2015 sebanyak 1.898 pasien.

Faktor penyebabnya diduga karena perubahan gaya hidup seperti kebiasaan makan makanan cepat saji, seringnya terpapar radiasi dari media elektronik dan perubahan kondisi lingkungan (YKPJ, 2011). Penyebab lain tingginya angka kejadian kanker payudara ini adalah karena terbatasnya pengetahuan masyarakat tentang bahaya dari kanker payudara, tanda-tanda dini, faktor risiko dan cara penanggulangannya (Yayasan Kanker Indonesia, 2012).
Mengingat adanya kecenderungan peningkatan jumlah penderita kanker, maka perlu dilakukan upaya untuk pencegahannya, Kemenkes RI telah melaksanakan program deteksi dini kanker payudara yang dikenal dengan metode SADARI (pemeriksaan payudara sendiri). Sadari adalah pemeriksaan payudara sendiri yang bertujuan untuk mengetahui ada tidaknya kanker dalam payudara wanita (Olfah, 2013).

American Cancer Society (ACS/2011) menganjurkan bahwa sadari perlu dilakukan oleh wanita usia 20 tahun atau lebih setiap bulannya yaitu pada hari ke-7 atau ke-10 setelah selesai haid. Namun seiring berjalan waktu, penyakit ini mulai mengarah ke usia lebih muda, maka usia remaja (13-20 tahun) juga perlu untuk melakukan SADARI secara rutin sebagai upaya pencegahan dan deteksi dini.

Hasil studi pendahuluan yang dilakukan terhadap 20 siswi MA Alfatah Natar, didapatkan bahwa 17 dari 20 remaja tersebut diantaranya sudah mengetahui tentang gambaran kanker payudara tetapi belum mengetahui tentang cara melakukan SADARI

\section{METODE PENELITIAN}

Rancangan penelitian ini bersifat analitik dengan pendekatan cross sectional. Variabel indepen yang diteliti adalah pengetahuan tentang pemeriksaan payudara sendiri (SADARI) dan variabel dependennya adalah perilaku SADARI. Penelitian ini dilaksanakan di MA ALFatah Natar Lampung Selatan pada Bulan April 2017. Populasi yang digunakan dalam penelitian ini adalah seluruh siswa kelas XI MA Alfatah Natar sebanyak 85 siswi. Teknik sampling yang digunakan dalam penelitian ini adalah simple random sampling. Penelitian ini menggunakan data primer dengan Instrumen yang digunakan adalah cheklist. Analisis data dengan univariat dan bivariat menggunaka chi square. 


\title{
Aisyah: Jurnal Ilmu Kesehatan 2 (1) 2017, - 83
}

\author{
Utama Ladunni Lubis
}

\section{HASIL DAN PEMBAHASAN}

Berdasarkan hasil pengumpulan data dan analisis data yang dilakukan, maka didapatkan hasil sebagai berikut:

Tabel. 1

Pengetahuan SADARI

\begin{tabular}{lcc}
\hline \multicolumn{1}{c}{ Pengetahuan } & Frekuensi & \% \\
\hline Kurang & 32 & 45,7 \\
\hline Cukup & 36 & 51,4 \\
\hline Baik & 2 & 2,9 \\
\hline Jumlah & 70 & 100 \\
\hline
\end{tabular}

Berdasarkan tabel. 1 dapat diketahui bahwa sebagian besar responden berpengetahuan cukup yaitu sebesar 36 responden $(51,4 \%)$.

Tabel. 2

Perilaku SADARI

\begin{tabular}{lcc}
\hline \multicolumn{1}{c}{ Perilaku } & Frekuensi & \% \\
\hline Belum Pernah & 56 & 80 \\
\hline Tidak Rutin & 14 & 20 \\
\hline Jumlah & 70 & 100 \\
\hline
\end{tabular}

Berdasarkan tabel. 2 diketahui bahwa sebagian besar responden belum pernah melakukan pemeriksaan SADARI yaitu sebesar 56 responden $(80 \%)$.

Tabel. 3

Hubungan Pengetahuan dengan Perilaku SADARI

\begin{tabular}{lccccccc}
\hline \multirow{2}{*}{ Pengetahuan } & \multicolumn{2}{c}{ Belum Pernah } & \multicolumn{2}{c}{ Tidak Rutin } & \multicolumn{2}{c}{ Total } & \multirow{2}{*}{$\boldsymbol{p}$ value } \\
\cline { 2 - 6 } & $\mathbf{N}$ & $\mathbf{\%}$ & $\mathbf{n}$ & $\mathbf{\%}$ & $\mathbf{n}$ & $\mathbf{\%}$ & \\
\hline Kurang & 26 & 81,3 & 6 & 18,8 & 32 & 100 & \\
\hline Cukup & 30 & 83,3 & 6 & 16,7 & 36 & 100 & \multirow{2}{*}{0,016} \\
\hline Baik & 0 & 0 & 2 & 100 & 2 & 100 & \\
\hline Jumlah & 56 & 80 & 14 & 20 & 70 & 100 & \\
\hline
\end{tabular}

Hasil analisis hubungan antara pengetahuan dengan perilaku SADARI diperoleh bahwa ada sebanyak 2 responden yang berpengetahuan baik tetapi tidak rutin melakukan SADARI, sedangkan sebanyak 26 responden $(81,3 \%)$ berpengetahuan cukup yang belum pernah melakukan SADARI. Hasil uji statistik diperoleh nilai $\mathrm{p}=0,016$ maka dapat disimpulkan ada hubungan yang signifikan antara pengetahuan dengan perilaku SADARI.

Hasil penelitian menunjukkan bahwa sebagian besar pengetahuan siswi kelas XI MA Al-fatah Natar adalah cukup yaitu sebanyak 36 responden $(51,4 \%)$. Tingkat pengetahuan yang cukup ini disebabkan karena banyak faktor, diantaranya lingkungan, masih kurangnya informasi yang diterima oleh siswi tersebut baik dari petugas kesehatan maupun dari media online serta usia karena hampir seluruh responden dalam penelitian ini adalah remaja (15-17 tahun) yang masih terbatas dalam mengakses informasi tentang SADARI baik dari internet, majalah, brosur ataupun sumber informasi lainnya. Hasil penelitian ini sejalan dengan penelitian yang dilakukan oleh Rosyidah, 2011 yang menunjukkan bahwa dari 182 responen diketahui sebanyak 80 responden memiliki pengetahuan yang cukup tentang SADARI.

Deteksi dini dan peningkatan kewaspadaan disertai pengobatan yang sesuai pada kasus kanker payudara dipercaya dapat menurunkan jumlah kematian karena kanker payudara, tingginya kasus kanker payudara yang disebabkan minimnya informasi dan rendahnya kesadaran wanita Indonesia untuk melakukan deteksi dini terhadap kanker ini. Kemampuan dan perilaku deteksi dini sebaiknya dimulai sejak masa remaja, dimana remaja adalah komunitas dengan rasa keingintahuan yang tinggi sehingga memberikan informasi sejak usia remaja sangat dibutuhkan.

Untuk itu remaja putri harus diberikan informasi tentang SADARI sebagai suatu metode pemeriksaan payudara yang efektif untuk menemukan tumor sedini mungkin 


\section{Aisyah: Jurnal Ilmu Kesehatan 2 (1) 2017, - 84}

Utama Ladunni Lubis

serta diharapkan adanya peran tenaga kesehatan maupun pengurus Klinik Pesantren untuk memberikan penyuluhan/pendidikan kesehatan secara berkesinambungan dan menindaklanjuti pemahaman materi yang diterima oleh sisiwi kelas XI di MA Al-Fatah Natar.

Berdasarkan Hasil penelitian menunjukkan bahwa sebagian besar responden belum pernah melakukan pemeriksaan SADARI yaitu sebesar 56 responden (80\%). Penelitian ini sejalan dengan penelitian Nurhayati, 2013 didapatkan data bahwa sebagian besar responden yaitu sebanyak 32 orang $(61.8 \%)$ melakukan SADARI, dan sisanya sebanyak 20 orang $(38,2 \%)$ responden tidak melakukan SADARI.

Menurut Mulyani (2013), jenis pencegahan kanker payduara dapat dilakukan dengan cara yang sederhana dan bahkan bisa dilakukan sedari dini terutama oleh remaja putri yaitu dengan pemeriksaan payudara sendiri. Perilaku SADARI untuk upaya pencegahan dini kanker payudara telah dilakukan oleh sebagian besar responden yang melakukan SADARI namun tidak rutin setiap bulannya. Banyak alasan yang diungkapkan oleh responden diantaranya malas, tidak sempat, malu, belum tahu tentang teknik SADARI serta ada yang beranggapan bahwa SADARI tidak penting untuk dilaksanakan.

Hasil penelitian dengan menggunakan uji chi square dinyatakan bahwa terdapat Hubungan Pengetahuan Remaja Putri tentang Pemeriksaan Payudara Sendiri (SADARI) dan Perilaku SADARI pada siswi kelas XI MA Al-Fatah Natar Tahun 2017, nilai $p$-value sebesar 0,016 dan nilai $p=\alpha<0,05$. Penelitian ini tidak sejalan dengan penelitian yang dilakukan oleh Nurhayati, 2013 yang menunjukkan bahwa tidak ada hubungan antara pengetahuan responden dengan perilaku melakukan SADARI, nilai $\mathrm{p}$-value $0,628(\mathrm{p}=\alpha<0$, 05).
Menurut pendapat peneliti, tidak dilakukannya pemeriksaan SADARI secara rutin setiap bulan pada responden yang memiliki pengetahuan baik kemungkinan disebabkan minimnya pengalaman responden terhadap paparan kasus kanker payudara seperti kemungkinan tidak ada anggota keluarga, kerabat atau orang lain yang pernah responden lihat mengalami kanker payudara. Pengalaman tersebut membentuk perasaan simpati, kecemasan maupun ketakutan sehingga menginduksi perilaku melakukan pemeriksaan payudara sendiri.

Menurut Suryaningsih (2009), SADARI merupakan salah satu cara yang lebih mudah dan efisien untuk dapat mendeteksi kelainan payduara oleh diri sendiri. Sedangkan Permenkes (2015) menerangkan bahwa waktu yang tepat untuk dilakukan periksa payudara sendiri adalah satu minggu setelah selesai haid (pada hari ke 7 sampai dengan hari ke 10 setelah hari pertama haid).

\section{KESIMPULAN DAN SARAN}

Berdasarkan hasil penelitian yang telah dilakukan dapat disimpulkan bahwa pengetahuan tentang Pemeriksaan SADARI pada siswi kelas XI adalah cukup, sebagian besar siswi kelas XI belum pernah melakukan SADARI dan ada hubungan yang bermakna antara pengetahuan tentang pemeriksaan payudara sendiri (SADARI) dengan perilaku SADARI pada siswi Kelas XI MA Al-Fatah Natar Tahun 2017.

Peneliti selanjutnya diharapkan dapat meneliti variabel lain yang berkaitan dengan perilaku SADARI dan menggunakan Uji Statistk yang lain. 


\section{Aisyah: Jurnal Ilmu Kesehatan 2 (1) 2017, - 85}

Utama Ladunni Lubis

\section{DAFTAR PUSTAKA}

Ali, Asrori. (2009). Psikologi Remaja, Jakarta: Bumi Aksara

Arikunto, Suharsimi. (2010). Prosedur Penelitian Suatu Pendekatan Praktik, Jakarta : Rineka Cipta

Dinas Kesehatan Provinsi Lampung. (2012). Profil Kesehatan Provinsi Lampung Tahun 2012. Bandar Lampung

Hastono, Sutanto Priyo. (2007). Analisis Data. Jakarta: FKM-UI

Infodatin Kemenkes RI. (2015). Pusat Data dan Informasi Kementrian Kesehatan Republik Indonesia. Jakarta

Kemenkes RI. (2015). Pusat Data dan Informasi Kementrian Kesehatan Republik Indonesia. Jakarta

Kusmiran, E. (2011). Kesehatan Reproduksi Remaja Dan Wanita. Jakarta: Salemba Medika.

Notoatmodjo, Soekidjo. (2007). Ilmu Prilaku dan Pendidikan Kesehatan. Jakarta: Rineka Cipta

Notoatmodjo. (2012). Metodologi Penelitian Kesehatan, Jakarta : Rineka Cipta

Nurhayati. (2013). Pengetahuan Kanker Payudara dengan Memeriksa Payudara Sendiri (SADARI) pada Siswi Sekolah Menengah Atas. Jurnal Keperawatan. Volumer IX, No. I

Olfah, Yustiana. (2013). Kanker Payudara dan SADARI, Jakarta: Nuha Medika

Permenkes no 34 tahun 2015. Penanggulangan Kanker Payudara dan Kanker Leher Rahim. Jakarta

Purwoastuti, Endang. (2010). Kanker Payudara, Pencegahan dan Deteksi Dini. Jakarta: Kaninus

Rosyidah, Nanik Nur. (2011). Hubungan
Pengetahuan Mahasiswa Kebidanan Tingkat II Tentang SADARI dengan Frekuensi Melakukan SADARI. Jurnal Keperawatan dan Kebidanan, Stikes Dian Husada Mojokerto

Sudarto, Himawan Sutisna, Tjarta Achmad. (2005). Buku Ajar Patologi I edisi ke- 1. Jakarta: Sagung Seto

Yayasan Kanker Indonesia. (2012). Kanker Payudara. Diunduh tanggal 25 April 2017 
Aisyah: Jurnal Ilmu Kesehatan 2 (1) $2017,-86$

Utama Ladunni Lubis 